\title{
Cascading flood compartments with adaptive response
}

\author{
E. Pasche ${ }^{1}$, G. Ujeyl ${ }^{1}$, D. Goltermann ${ }^{1}$, J. Meng $^{2}$, \\ E. Nehlsen ${ }^{1} \&$ M. Wilke ${ }^{1}$ \\ ${ }^{1}$ Institute of River \& Coastal Engineering, \\ Hamburg University of Technology, Germany \\ ${ }^{2}$ Björnsen Consulting Engineers, Koblenz, Germany
}

\begin{abstract}
In consequence of the climate change, a sea level rise within the coming decades is highly probable and the intensity of storm surges will probably increase at least in the North Sea region. In this changing environment, great uncertainty exists about the need to adapt conventional coastal flood protection structures. This calls for response strategies to improve the flood resilience behind the dikes, in the Hinterland. Within this paper, the concept of cascading flood compartments is presented as an appropriate strategy to deal with the residual risk in the Hinterland. The key element of this approach is that an overtopping of the main dike line is accepted requiring their enforcement to resist erosion from hydrodynamic loads. Inner dikes are arranged in a multi-layer cascade of compartments creating a redundant system of flood containment. The necessary adaptations and restrictions to the built environment vary from simple resistance measures of dry- and wet-proofing to the development of amphibious settlements with floating homes and houses on piles. The whole concept is illustrated on the island of Wilhelmsburg in Hamburg, where urban areas are protected against storm surges through a ring dike. The necessary storage capacity of the flood compartment system is determined for the climate change scenarios of 2030 and 2085. A realistic arrangement of flood compartments can be found, proving the effectiveness and efficiency of this response strategy. $3 \mathrm{~d}$ graphics illustrate the transfer from a water-abandoned city to an amphibious city, backing the statement that this flood response strategy opens new opportunities for cities.
\end{abstract}

Keywords: climate change, flood risk management, cascading flood compartments, flood response strategy, amphibious cities. 


\section{Introduction}

The latest publications [2, 3] show that climate change will amplify the sea level rise within the coming decades and will increase the intensity of storm surges. Grossman et al [3] predicted storm surges for the German Bay and the Elbe estuary, which will be up to $85 \mathrm{~cm}$ higher in 2085 . Thus, in the future a redesign of coastal flood protection systems seems to be inevitable. But is dike raising the adequate response strategy or do we need a paradigm change in flood management, which no longer regards the area behind the dikes as safe?

At the Institute of River and Coastal Engineering in Hamburg, research has been carried out to find the right answer to cope with the increasing risk of dike failure due to climate change in the coastal zones and along the estuaries. A new strategy of flood risk management has been invented which accepts the controlled flooding of the Hinterland. Through a set of coordinated resilience measures the damage can be kept at an acceptable level.

Within this paper this new concept of flood risk management is presented, the necessary adaptation measures of the existing dikes and the built environment are explained. At the Elbe island "Wilhelmsburg" in the city of Hamburg, the applicability of this concept to cities along the coast line and in estuaries is demonstrated and its performance compared with the traditional defence strategy of dike raising.

\section{A theoretical discourse about the consequences of climate change on flood management}

According to the EU Flood Directive, flood management should be risk management, which continuously and in a holistic way analyses, assesses and takes actions to reduce the flood risk in consensus with society. To understand the options of flood risk mitigation the Source-Pathway-Receptor-Consequence (S-P-R-C) model (see http://www.floodsite.net/html/faq2.htm) is very helpful. In this conceptual model a risk has a source, which in our case is the hazard event of extreme water stages in the river due to a storm surge. Along a pathway (flood routes on the flood plain including the defence structures), the flood water will propagate to the receptor (the properties, people or habitats on the flood plain), where the flood will have consequences for the receptor depending on the vulnerability of the receptor and the intensity of the exposure. Flood mitigation has many options to reduce the flood risk through changing any of these four elements of risk generation. In the past, flood management was in general restricted to a pathway control through dikes and walls. The disadvantage of this strategy is the finiteness of its effectiveness. For flood events above the design flood the structures will loose their containment function and even cause a more disastrous flood through the breaching of dikes, giving reason to classify them as designed for failure. The consequence is illustrated in fig. 1. Due to today's practice of flood management, which in general does not include risk management in the Hinterland, the population will be unprepared in case of unexpected flooding leading to high damages. In particular, the indirect damages 
will cause a lasting impact on society and economy that the system will not recover from quickly. An example of this consequence is the dike failures and unexpected flooding of the city of New Orleans caused by hurricane Katrina in 2005. More than two years after the catastrophe the city has not yet recovered.

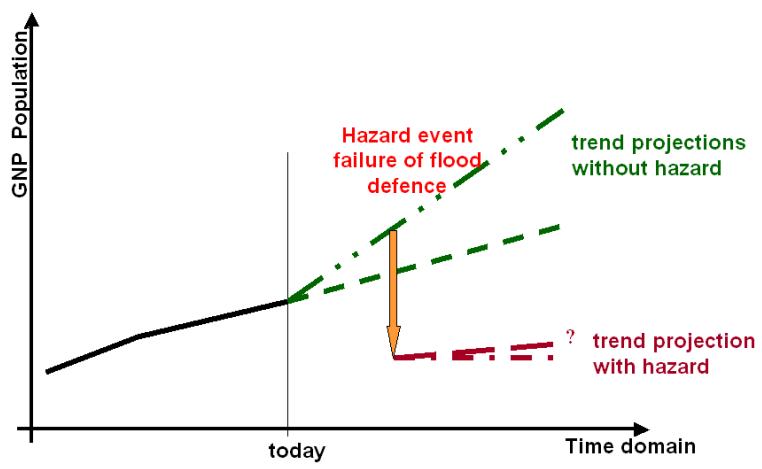

Figure 1: $\quad$ Hazard response in case of insufficient flood resilience.

The probability of these events of failure will increase in the future due to climate change. Entrapped by the present practice, water authorities react on this increasing residual flood risk with the intention to raise the height of the dike. But they are confronted with the obstacles as dike raising is cost intensive, needs long implementation periods, has a strong impact on ecology and the projections of climate change are too uncertain for deriving assured design high water levels. This means that dike raising is not flexible enough to cope with the uncertainty of climate change and thus is not the right answer for adapting the residual flood risk in the Hinterland. The avoidance of failure should not be the strategy, rather reducing the consequence of failure. This leads to failure response strategies, which control the pathways behind the dikes and/or the vulnerability of the built environment, infrastructure and population in the Hinterland.

\section{Hazard response strategy of cascading flood compartments}

The system of cascading flood compartments (CFC-approach) represents a failure response strategy, which affects both the flooding of the Hinterland and the vulnerability of the objects on the flood plains. Inner dikes are built to contain the flood water in the Hinterland. They are formed to closed lines creating a system of polders termed as flood compartments. Different priorities to flood these compartments are given to cope with the uncertainty of the hazard event. This will lead to a system of cascading compartments. In principle, they are arranged as belts of compartments parallel to the primary dikes establishing a multi-layered buffer zone, which can be regarded as a redundant system of flood containment structures (Fig 2).

Within each compartment adaptations and restrictions of the existing built environment, infrastructure and farmland are necessary. They need to reflect the 


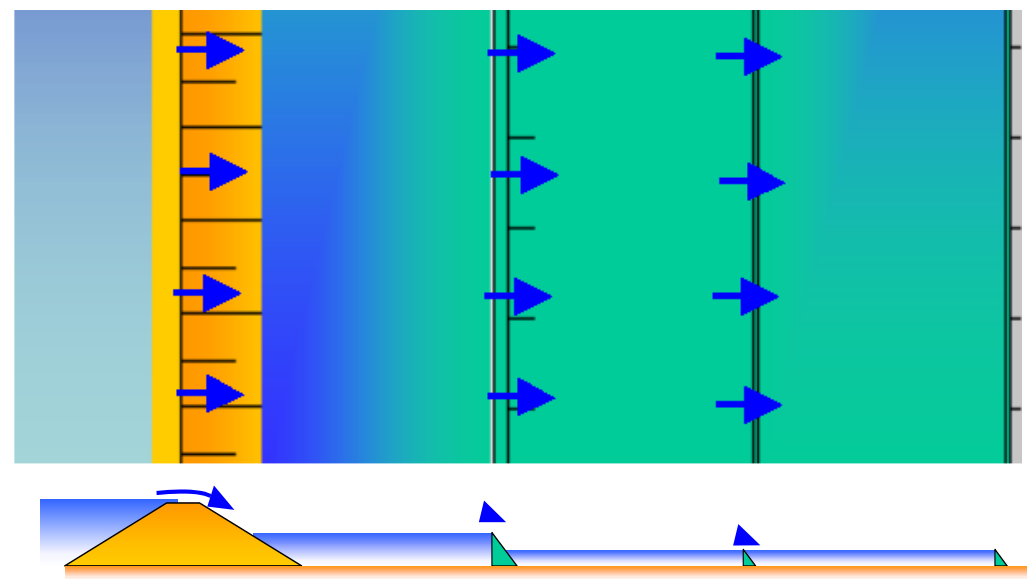

Figure 2: $\quad$ Principle of a cascading system of flood compartments.

different probability of flooding within each compartment and the exposure to the flood wave. The relevant design criteria are the remaining flood risk within each compartment. It should be the same for all compartments according to fig. 3. The consequence is that the rate of adaptation to a possible flooding is varying in each compartment in dependence on its position within the compartment cascade. The more compartment layers are between the main dike line and each single compartment the less is the rate of adaptation in it and vice versa. A risk assessment analysis will help to find the right measures. In the end the overall residual risk within the Hinterland will be much lower than without the CFCapproach and it will be everywhere the same no matter being in or outside the compartment cascade, a capacity which is most relevant for the acceptance by the population living in the Hinterland.

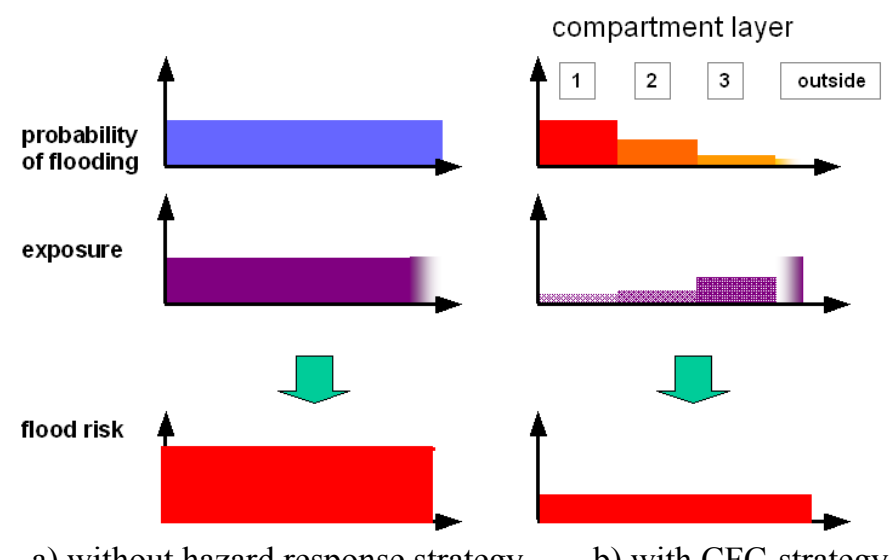

a) without hazard response strategy

b) with CFC-strategy

Figure 3: Risk distribution in the Hinterland is dependent on the resilience. 


\section{Design elements of the compartment system}

The efficiency to reduce the containment of flooding the Hinterland depends strongly on the stability of the main dike in case of overtopping. In general, dikes are not designed for this hydrodynamic load. Thus, part of the cascading flood compartment concept is the enforcement of the dike surface. Various techniques are available [6] and will not be further regarded here.

Concerning the arrangement of the compartments, existing natural or artificial ridges should be used reducing the need to built new dikes. Often remainders of old dikes (sleeping dikes) are in the Hinterland or embankments of roads or railroad tracks can be used as inner dikes. As a hazard control system the height of the inner dikes should be kept low with a maximum of 2,0 $\mathrm{m}$ within the first compartment. The dikes of the outer compartment layers should not exceed a height of $1,0 \mathrm{~m}$. In this case, the hydrodynamic load on the inner dike structures is so low that no additional geotechnical measures are necessary to ensure their stability. In addition to earth-fill dams non-permanent dikes are needed to close temporary traffic lines, open places and other areas, which need to be kept clear. In the last years, the technique of dismountable walls has improved so much that nowadays a large number of products are available. They range from very reliable flood barriers, which connect their pillars with permanent foundation structures (Fig. 4a), and simple emergency type systems (Fig. 4b), which are

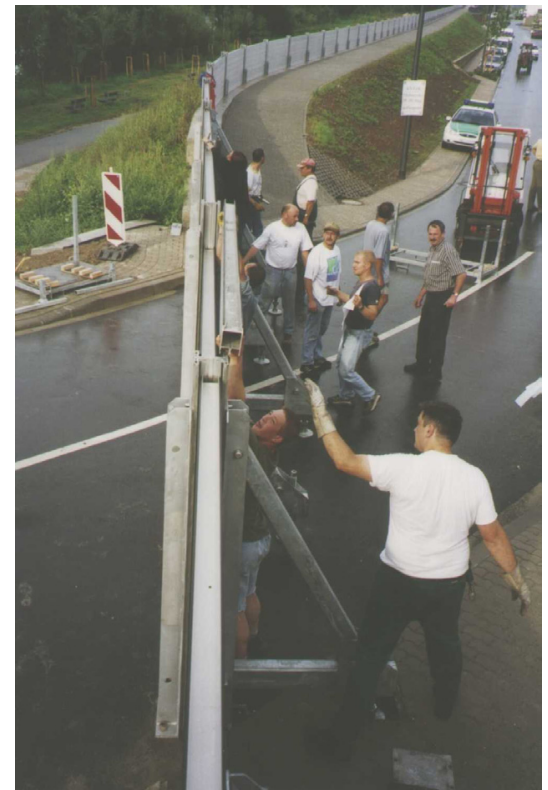

a)

\begin{abstract}
Movable
wall

with permanent anchor plates.
\end{abstract}

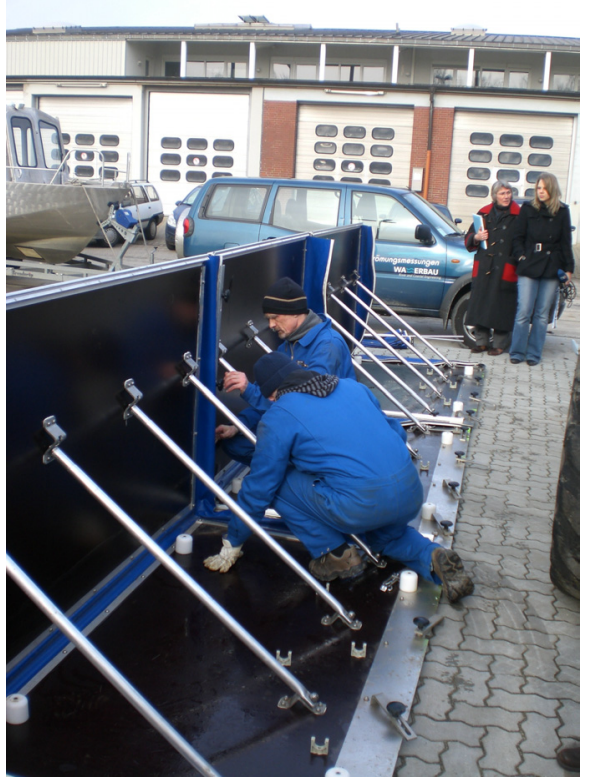

b) Emergency type flood wall without permanent structures.

Figure 4: Dismountable walls for flood containment. 
deployed on the surface without any connection to the underground [1]. Thus they can be applied very flexible and their deployment can be adapted to the needs in case of flooding. In addition the propagation of flood through drainage pipes, sewers and watercourses needs to be prevented through temporary gates.

\section{Adaptation measures for the built environment}

As explained in chapter 3 the built environment has to be adapted to the residual risk within each compartment. This need of adaptation can be regarded as an opportunity for the urban environment along the coastline and estuaries because in general the flood defence system of dikes has disconnected the flood prone areas of the cities from the waterfront, leading to an urban developed which does not differ from inland cities as dike failure or overtopping was not taken into account. With the probability of flooding the Hinterland can now restore its natural potential of an amphibious eco-system where all habitants can live under both conditions, dry and flooded. These cities can redevelop their waterfront and maritime character. While urban development is finite when continuous sea level rise will be compensated through continuous dike rising, an amphibious city will be able to gradually adapt to the sea level rise. At the beginning of the transfer process the existing built environment can be flood proved through simple structural resistance measures, e.g. closing of all openings with dismountable flood gates, sealing or shielding of the masonry and sealing of wall penetrations around supply lines (dry-proving technologies). Other options are the use of water resistant material and the allocation of the interior equipment to higher regions of the building (wet-proofing). These resistance measures are very effective and efficient for flood depths less than one meter [4]. Later on when climate change will lead to higher water depths within the compartments, the adaptation needs to be more profound at the existing build environment. Probably the terrestrial buildings have to be replaced by amphibious houses, which are built on earth embankments, piles or on pontoons to make them floatable (fig. 5).

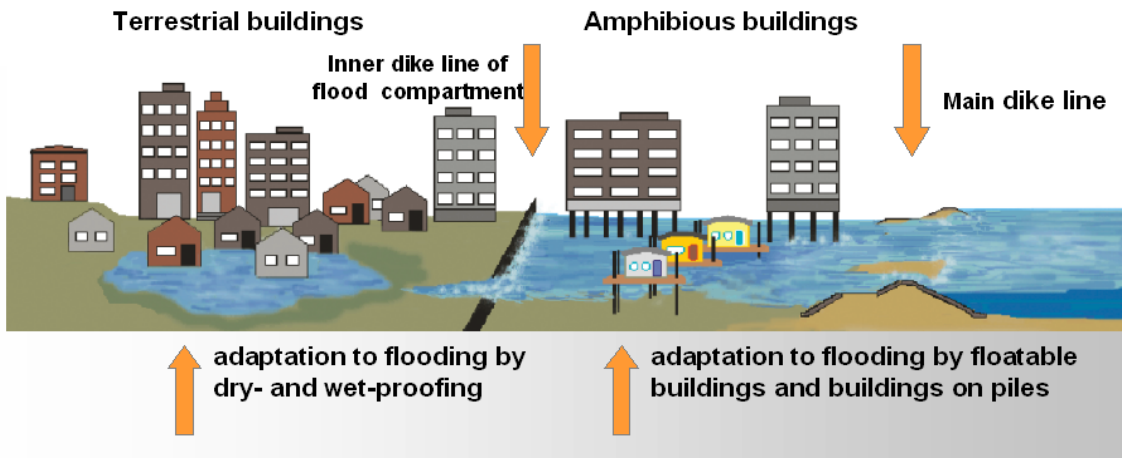

Figure 5: Principle of the adaptation strategy for the build environment. 
Amphibious houses are always recommended in the front belt of compartments independent of the water depth because the overtopping or breeching of the dikes will generate strong currents here. Houses on piles or on floating structures can stand these loads easily whereas terrestrial buildings need enforcement. The transfer to amphibious buildings means definitely a radical change of the built environment. But it's an inevitable step for all cities along the coastline and estuaries, which are threatened by continuous sea level rise. The sooner this transfer is started the more sustainable are investments in the built environment.

The adaptation process has a strong impact on the process of urbanization within each compartment. Regulations and master plans are necessary to coordinate the adaptation measures and to restore the natural potential of an amphibious city.

\section{An example of application}

In the city of Hamburg/Germany the Elbe estuary bifurcates into a northern and a southern branch, forming an island in the middle called Wilhelmsburg (fig. 6). It is part of the urban area, but still with a high potential of further development. This has been discovered by the policy which launched a new development programme for Wilhelmsburg, "Leap across the Elbe" (http://www.sprungueber-die-elbe.de), which will create new homes for 30.000 to 40.000 citizens on this island. Although more than $100 \mathrm{~km}$ away from the North Sea the Elbe estuary has still a tidal range of $3.5 \mathrm{~m}$ at Hamburg. Every year Hamburg is threatened by storm surges which in 1962 led to a catastrophe, flooding wide parts of the city and especially the island Wilhelmsburg where more than 300 people drowned. This led to a dike enforcement programme in which a ring dike around the island has been raised twice in the last 40 years. Today the design high water stage for this dike system is $7.30 \mathrm{~m} \mathrm{ASL}$, which is about $85 \mathrm{~cm}$ higher than the highest recorded flood. Due to a free board that varies in dependence on the expected wave height the crest height of the dikes varies between $7.70 \mathrm{~m} \mathrm{ASL}$ and $8.35 \mathrm{~m}$ ASL. Thus at present the dikes seem to provide sufficient safety to overtopping. But if the sea level rise is taken from the climate change scenarios of Grossmann et al [3] then already in 2030 the design storm surge will lead to an overtopping of the dikes and 4 million $\mathrm{m}^{3}$ of water will flow onto the Hinterland of the island. In 2085 the flood volume goes up to 15 million $\mathrm{m}^{3}$. In this case nearly all urban areas on the island will be flooded similar to the situation of 1962 (fig. 6).

The CFC-method has been tested in its capacity to mitigate this flooding. The selection of compartments had to consider the following restrictions and requirements:

- protection of the population and the industrial areas

- protection of the main escape routes off the island (motorway, railway track)

- exclusion of special zones (waste deposit, cemetery, nature protection areas) 
- use of topographical elevations (former dikes, elevated alignments)

The polder areas and locations of the inner dike lines were found on the basis of an optimisation process. According to the local situation and the required storage level simple earth-fill dams, retaining walls and dismountable walls are used to form the defence line of the compartments. Fig. 7 shows a possible solution for a cascading compartment system. The different colours indicate the different layers of the cascade. The maximum volume to be retained in this whole system reaches 15 million $\mathrm{m}^{3}$ with an average water depth of $1.80 \mathrm{~m}$ in the compartments. Consequently the system is able to contain the overtopping flood water predicted for the climate change scenario 2085. The most developed urban area indicated by the dashed line can be preserved from flooding indicating a substantial efficiency of flood containment.

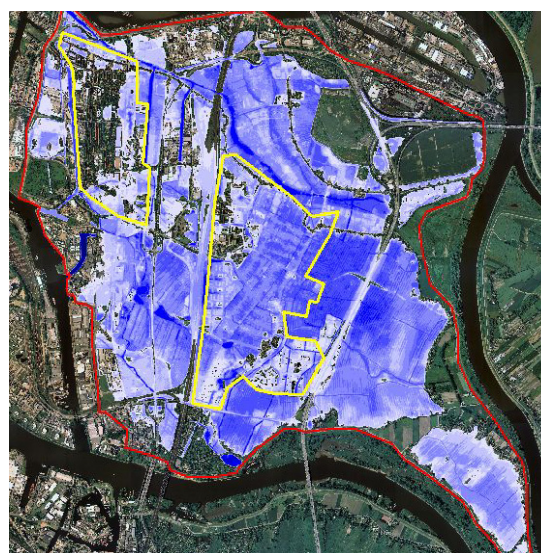

Figure 6:

Predicted flooding of
Wilhelmsburg for
climate change
scenario 2085 .

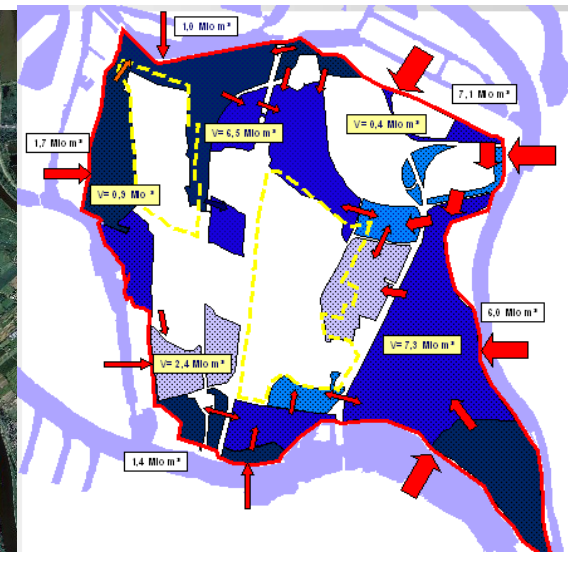

Figure 7: Possible cascading compartment system for the Hinterland of Wilhelmsburg.

The determined cascading compartment system for Wilhelmsburg is flexible enough to adapt to changes in the prediction of the climate. It makes extensively use of existing sleeping dikes within the main dike line and dismountable flood barriers according to fig. 4. For the adaptation of the built environment the principles given in chapter 3 and 5 have been applied.

Together with city planers the adaptation measures have been integrated in an innovative urban developed plan in which floating homes, homes on piles and amphibian homes are arranged in an attractive way creating new urban water fronts with amphibious settlements (fig. 8).

The costs for the structural measures at the main dike line and the inner dikes have been determined to 90 million Euro. This includes the enforcement of the dike surface with the new composite, the elastomeric revetment [5], the restoration of the existing sleeping dikes, the purchase of dismountable walls and the installation of gates in the watercourses and drainage system. Alternatively 
the rising of dikes by $80 \mathrm{~cm}$ (necessary to compensate sea level rise due to climate change for the time horizon 2085) will cost about 140 million Euros proofing a higher efficiency of the cascading compartment system than the traditional mitigation measure of dike rising.

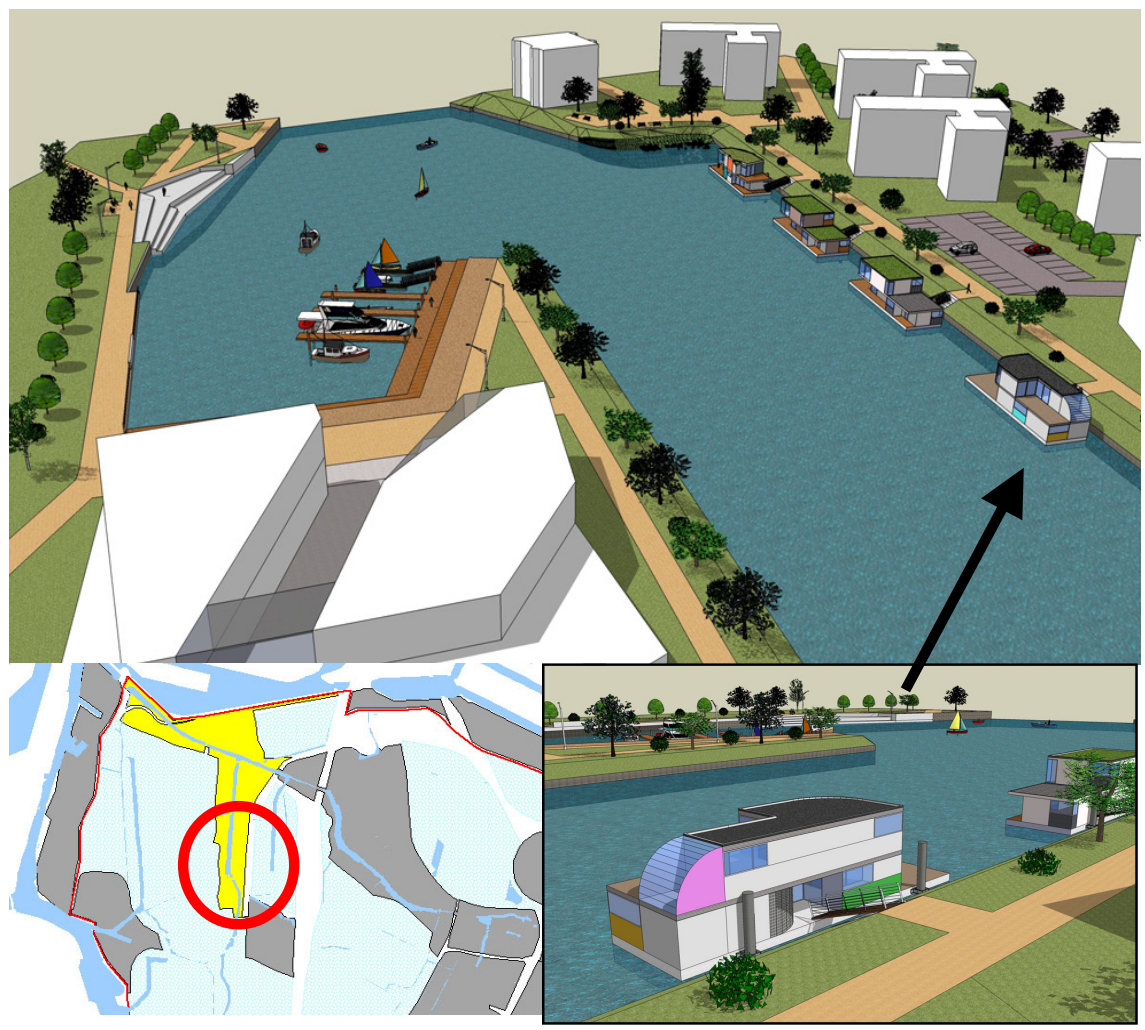

Figure 8: Visualization of the adaptation plan for the compartment Assmann Canal on the island of Wilhelmsburg.

\section{Conclusions}

It could be shown that climate change requires a new flood risk policy for the area behind the dikes. The CFC-approach has been found to be an efficient and effective strategy to cope with this increased residual flood risk. It could be shown by a case study at the Elbe island Wilhelmsburg in Hamburg that this concept can retain under certain conditions all flood water within the compartments that might overtop the main dikes lines as a consequence of climate change. As a long-term strategy of flood risk management it will be carried out stepwise giving city planners enough time to adapt the built environment to the increased risk of flooding within the compartments. This clears the way for implementing new forms of living at water by creating multi- 
functional spaces in which the infrastructure and all buildings are resistant to flooding. Compared with the expensive method of dike rising, the new concept has the same efficiency to reduce flood risk. In the presented case study the costs of investment to adapt the first dike lines and to build the inner dikes have been less than raising the dikes by $80 \mathrm{~cm}$. Additionally the necessary adaptation measures at the buildings will keep the risk awareness alive within the population. The greatest advantage is its flexibility to gradually adapt to changes in the climate change process.

Thus, cascading flood compartments with adaptive response to the built environment can be considered as an economical and sustainable concept in managing the increasing risk of climate change in urban environments prone to flooding by storm surges.

\section{Acknowledgement}

This research work is part of the BMBF-National Research Programme "Risk Management of Extreme Flood Events" (www.rimax-hochwasser.de) and is funded by the German Federal Ministry of Education and Research. It can be referenced under the registration number RIMAX $0330760 \mathrm{~A}$.

\section{References}

[1] BWK (2005): Mobile Hochwasserschutzsysteme - Grundlagen für Planung und Einsatz, BWK 6/BWK, ISBN 3-936015-19-8

[2] IPCC (Intergovernmental Panel on Climate Change) (2007): Climate Change 2007 - The physical science basis, Working Group I Contribution to the fourth assessment report of the IPCC

[3] Grossmann, I., Woth, K., von Storch, H. (2006): Localization of global climate change: Storm surge scenarios for Hamburg in 2030 and 2085, Die Küste, 71, 169-182

[4] Pasche, E., Geissler, T. R. (2005): New strategies of damage reduction in urban areas prone to flood. In: Szöllösi-Nagy, A., Zevenbergen, C.: Urban Flood Management. A. A. Blakema Publishers. Leiden/ London/New York.

[5] Pasche, E.; von Lieberman, N.; Evertz, T (2006) Elastomerical Revetments - A new way of coastline protection. Proceedings ICCE 2006 Conference

[6] Queißer, Jan (2006): Entwicklung landschaftsverträglicher Bauweisen für überströmbare Dämme. Mittlg. Institut für Wasser und Gewässerentwicklung, Universität Karlsruhe, Heft 233, Universitätsverlag 